\title{
TEACHER EFFECTIVENESS: AN ISSUE IN EDUCATIONAL ADMINISTRATION
}

\author{
Mirinda Coetsee, B.A. (Nurs) Potchefstroom, MS (Psychiatric and Mental \\ Health Nursing) Texas Woman's University, DNE (Pretoria)
}

\author{
Currently a doctoral student at the University of \\ Alabama in Birmingham, USA.
}

\section{OPSOMMING}

Die skrywer van die referaat het oorweging geskenk aan die rol van die dekaan in die oplewing van haar fakulteit as een van die maniere om sy lede tot bekwame onderrig aan te spoor. Wat 'n dekaan is, het net so 'n uitwerking op fakulteitslede as wat sy sê.

\section{INTRODUCTION}

$\mathbf{M}$ $\mathrm{UCH}$ of the lustre of the 1950-60 era of an abundance of faculty positions, polite students, and a swift increase in salary has changed considerably. A paucity of faculty positions, student revolts, and a declining economy are present-day realities. Faculty members are enjoined to do more socially profitable research, to teach more students and more courses. They are admonished to understand students', to be interested in their development, to be 'relevant' in their teaching, and are constantly reminded that learning involves more than mastery of the abstract content of the discipline.

Teaching in this decade has therefore become a complex endeavour, as evidenced by a copious amount of literature dealing with the mounting concern about mediocrity of thought and performance in teaching. Teaching effectiveness or excellence in teaching has thus become one aspect of education that has been frequently discussed by a multitude of educators and citizens. How to define, identify, measure, and evaluate excellence and how to detect and remove obstacles to its achievement have thus become a matter of pivotal importance.

This article will therefore deal with teacher effectiveness as an issue in educational administration, delineating the role of the dean in promoting effectiveness in her faculty.

\section{THE EFFECTIVE/EXCELLENT TEACHER}

The literature reveals a profusion of studies on teacher effectiveness. The term connotes the inclination and ability to play effectively the role of a teacher in the process of learning. Such effectiveness depends on a clear and developing concept of that role, personality traits of a special order, much professional knowledge, many highly developed skills, and a particular art that expresses itself in a special style (Pullias, 1963).
For more than a half century, researchers have investigated every minute aspect of effective teaching. Teacher training, traits, behaviours, attitudes, values, abilities, sex, weight, voice quality and a myriad of other characteristics have been considered. Teacher ef fectiveness has been judged by investigators themselves, pupils, administrators, parents, master teachers, practice teachers and by teachers themselves (Biddle and Elena, 1966). And yet, all this research has not yielded meaningful, measureable criteria of standards agreed upon by all as the criteria for effective teaching (Mitzer, 1960).

Teaching, Highet (1950) believes is an art, not a science. It involves emotions, which cannot be systematically appraised and employed, and human values which are quite outside the grasp of science. Teaching is like painting a picture or making music. You must throw your heart into it, you must realize that it cannot all be done by formulas, or you will spoil your work, your students and yourself.

Numerous characteristics of the effective teacher have been described. Pullias (1963, p.42) succinctly summarized the almost universal traits of the great teacher as:

1. Integrity and authenticity: A freedom from phoniness or pretence, an approach to genuineness and utter sincerity.

2. Enthusiasm and zest: An ardent belief in the significance of what one is doing and the energy to put life into it.

3. Directness or nearness to reality: An almost childlike relation to things and people, an elemental quality of immediacy that escapes the deadening heavy hand of pedantry and over-abstraction.

4. Perspective and length and breadth of view: Manifested frequently in a sense of humour, patience, freedom from the scourge of perfectionism.

5. Freedom of mind, especially freedom of imagination, an eagerness to consider many alternatives. 
6. Breadth of interest, and a sensitivity to a wide spectrum of life: manifested in wide reading and varied concerns.

7. An abiding concern for the individual learner: An ability to feel and communicate the notion that the individual learner is significant, that he has potential of great worth and that it can be realized.

The effective teacher must therefore be alive and growing, growing in knowledge and being. John Henry Newman remarked that the general principle of any study may be learned from books at home, but that "the colour, the tone, the air, the life which makes it live in us" must come from one in whom these qualities dwell. Such teaching has authenticity because it is a genuine and engaging projection of a particular life. The good teacher is thus a connoisseur, who leads others to a sense of his sensitivity. Connoisseurship is communicated primarily by example, not simply by precept (Polayni, 1958).

In conclusion it is obvious that excellence in teaching requires the spirit and tenacity, the questing, the dissatisfaction with anything not one's best, the working habits of a seeker of surpassing goodness, the patience and the bearing of disappointment, the tenderness and compassion of a great man (Pullias, 1963).

An excellent teacher will in the final analysis then view his task as portrayed by Phenix (1975, p.7) “. . . what stands out for me in my teaching experience is not what I or others regard as my successes or failures but the gratitude I feel for the unparalleled privilege of participating in one of the most exhilarating activities of mankind - the social celebration of the meaning of human existence in all its majesty and mystery."

\section{THE ROLE OF THE DEAN}

The road to excellence in teaching is open for exploration, and the choice between excellence and obsolescence has become mandatory - also in schools of nursing. True, much of excellence in teaching has to do with inherent qualities of personality and characteristics, but there is also a science aspect of teaching which involves a great deal of knowledge things that can and must be learned. One of the avenues to promote excellence in teaching is the dean, and her role to add renewed vigour in her faculty's performance.

Obviously, if the dean wants to invoke excellent behaviour in her faculty, she should epitomise humanistic and outstanding behaviour herself. Much of her guidance and many of her decisions will be based on her theoretical foundations and philosophical assumptions about man, the nature of society, the nature of education and the relationship between these. This writer contends that a conglomeration of several concepts from the theories of Rogers and Maslow, ad- ministrative, leadership, and role theory will assist the dean in her objective of faculty development so that they can function effectively with increasing autonomy, in harmony with their internalised goals and values.

McGregor (1966) contends that people are not by nature passive or resistant to organizational needs, but that they have become so as a result of experience in organizations. The motivation, the potential for development, the capacity for assuming responsibility, the readiness to direct behaviour toward organizational goals are all present in people. It is, therefore, the responsibility of the dean to make it possible for her faculty members to recognise and develop these human characteristics for themselves. She needs to assist them in becoming cognisant of the past experiences that have led to the careers they have chosen. They need to know how they have been influenced by graduate school, by socialisation in their discipline and by faculty culture. They need some understanding of personal development in adult years, insight into the forces of society at large and those of their colleges and universities that impinge directly on them. The essential task of the dean then is to arrange school conditions and methods of operation so that faculty members can achieve their own goals best by directing their own efforts toward school objectives. This is a process primarily of creating opportunities, releasing potential, removing obstacles, encouraging growth, providing guidance. It is management by objectives in contrast to management by control.

This process can only evolve through an authentic relationship between the dean and her faculty. Carl Rogers $(1961,1962)$ succinctly describes the care of such a relationship which this writer sees as an imperative to promote growth and excellence in teaching:

Congruence. Personal growth is facilitated when the dean is real and genuine, without front or facade, openly being the person she really is when she comes into direct personal encounter with her faculty.

Empathy. She gets an accurate understanding from the teachers' behaviour, of part of her world and she communicates some of that understanding back to the teacher without getting so involved that objectivity is lost.

Positive Regard. She enables growth and change when she exhibits a warm, positive, acceptant attitude toward her faculty. Not paternalism, not sentimentalism nor superficial sociableness or agreeability - but non-possessive respect for her and her potentialities.

Unconditional Regard. Not making judgments about the teacher and her worth as a human being, but exhibiting an outgoing positive feeling without evaluation. 
No doubt, the dean has to be an effective leader to incite her faculty to excellence. Her leadership must enable her to get her faculty to do willingly what they have the ability to do, but might not spontaneously do on their own. It implies that she has a special effect on others which commands their respect, admiration or affection and causes them to follow her. This implies a certain amount of assertiveness in the sense that she projects some part of her personality on others. It does not mean aggressiveness or force or coercion. Whether she influences by personal example, persuasion or empathetic feedback, she influences others by influencing their willingness to act rather than by forcing their compliance. She strives to become aware of the abilities of her subordinates and associates so she can guide them only towards goals which realistically they are capable of attaining (Greenberg, 1968).

Maslow on the other hand contends that all behaviour is prompted by needs to gain and maintain a sense of well-being but that meaningful activity only occurs when tangible goals are perceived. To assist her faculty in breaking out of complacency, to identify their unsatisfied needs and set goals to get those needs met, is an opportunity for the dean to assist in further growth and development of her faculty and finally for autonomy and full maturity as human beings (Kampmeier, 1970).

Levinson (1970, p.35) wrote about this in terms of an organization which is also applicable to the school situation:

\begin{abstract}
"The organizational task becomes one of first understanding man's needs, and then with him, assessing how they can be met in this organization, doing what the organization needs to have done. Thus, the highest point of self motivation arises when there is a complementary conjunction of the man's needs and organization's requirements. The requirements of both mesh, interrelate, and become synergistic. The energies of man and organization are pooled for mutual advantage."
\end{abstract}

Gordon (1974) suggests the technique of establishing a "win-win" contract. On the surface there seems to be a conflict of needs between dean and teacher, an attempt to accomplish personal goals at the expense of each other. The "win-win" contract helps both parties focus on accomplishing their goals in co-operation rather than in conflict and confrontation. The teacher is asked to participate in a joint plan that will accomplish both persons' goals. Both parties will each offer possible solutions and critically evaluate them to eventually create a plan of action acceptable to both. No selling of the other person will be required after the plan has been selected, because both have already accepted it. No power will be required to face compliance because neither is resisting it (Kampmeier, 1970).

Looking at it from a different perspective, Sergiovanni (1975) observed that supervision is a neglected art in need of revival:

\begin{abstract}
"The evidence is mounting that significant changes in school effectiveness will not come about as a result of increasing salaries of teachers, decreasing classes, introducing new materials, beefing up the academic training or certification, credentials of teachers, reducing the work load, introducing clerical assistance, using performance contracts and the like... the highly motivated teacher must become a high priority concern of supervisors."
\end{abstract}

Schlotfeld (1976, p.148) wrote that:

"The quality of any nursing education enterprise is directly related to the quality of the faculty; they are the means through which high calibre educational, research and nursing care programs can be achieved. Of primary concern, then, to corporate faculties and administrators are the recruitment, selection and continued development of new faculty members with appropriate competencies and professional aspirations. Of equal concern in the process are the goals of prospective faculty members themselves, as they seek a setting in which they can use their own abilities most productively and, at the same time, experience an educational climate that will promote their growth and development as professionals and scholars."

\section{SUMMARY AND CONCLUSIONS}

So many things contribute to the sum total of effective teaching that no person can possess all of them. No teacher can be the most intelligent, the best informed and at the same time illuminate the classroom with the force of her personality and the magnificence of her lecture. However, she can be enthusiastic and dedicated. These are attributes which can be developed, cultivated and transmitted to students. A dedicated teacher can make her students believe that what she is teaching is worth knowing and more important, convey some of this enthusiasm to her students.

Much has been written over the years about all aspects that would contribute to teacher effectiveness: seminars for improved teaching, release of time, exchange of professorship, leave of absence, sabbatical leave, small grants to teachers for special pedagogical efforts, systematic review procedures for faculty, entrepreneurship and innovation in consortia, salary increases, promotions and tenure, and numerous other intrinsic rewards.

The writer of this paper has considered the role of the dean in the revitalisation of her faculty as one avenue to stimulate its members to excellence in teaching. Faculty members learn as much from a dean from what she is as from what she says.

Perhaps there is no better way than but to conclude with the words of Michael Polayni (1958): 
"By watching his master and emulating his efforts in the presence of his example, the apprentice unconsciously picks up the rules of an art, including those which are not explicitly known to the master himself."

\section{BIBLIOGRAPHY:}

Aschner, M.J. and Bish, C.E. Prnduclive Thinking in Educatinn. The National Education Association and The Carnegie Corporation of New York, 1965.

Aikinson, B. (Ed.) College in a Yard. Cambridge: Harvard Press, 1958.

Biddle. B.J. and Ellena, W.I. Contemporary Research on Teacher Eifectiveness. New York: Holt, Rinehart and Winston, 1964.

Buxion, T H. and Prichard, K.W. Excellence in University Teaching. Columbia, S.C University of South Carolina Press, 1975.

Danield, P.R. et al. A "Floating Faculty" - An Intensive In-Service Technique. Educational leadership, 1976, Vol. 33, No. 5, p.355-8.

Drucker, P.F. Mangging far Results. New York: Harper and Row Pub., 1964

Freedman, H, (Ed.) Facilitating Faculty Developmenı. Washington: Jersey Bass Inc., Pub. 1973.

Faculty Development in a Time of Retrenchment. The Group for Human Development in Higher Education and Change Magazine, 1974.

Gardner, J.W. Excellence. New York: Harper and Brothers 1961

Gordon, T. T.E.T. Teacher Effectiveness Training. New York: Peter H. Wyden Publisher, 1974, Chapters 89

Greenberg, H. M. The Personality Dyngmics Inventory Evaluation. Princeton, Marketing Survey and Research Corp., n.d. 1965.

Highet, G. The Arr of Teaching. New York: Random House Inc., 1950.

Hildebrand, M. "The Characier and Skills of the Effective Professor." The Journal of Higher Fducalion, 1973, 44, 41-50.

Hoffer, E. The Ordeal of Change. New York: Harper, 1963.

Hoffman, R.W. "Students Portray the Excellent Teacher." Improving Callege and University Tegching, 1963, 11, 21-24.

Jacobs, P.E. Changing Values in College. New York: Harper and Brothers, 1957

Jenson, G. "Preparing Competent Teachers of Teachers". Educalional Leadership, 1973, 30, 5. 429-30.
Kampmeier, C. "Creative Leadership in the School." Thenry into Practice, 1970, 15, 5 , pp 360-65.

Kegel, C.H. "The Distinguished Teacher." Impraving Callege and University Teaching, $1964,12,102-04$

Keller, Helen. Teacher: Anne Sullivan Macy. Garden City, New York: Doubleday \& Co., 1955

Landers, A.D. Evaluating Teachers. In "On College Teaching" by Milton, et al. Washingion: Jersey-Bass Pub., 1978.

Levinson, H. "Management by Whose Objectives." Harvard Business Review, July-August, 1970 , pp $34-40$

Lundsted 1 , S. "Criteria for Effective Teaching." Improving College and University Teaching. 1966, 14, 27-31.

McGregor, D. Ieadership and Molivation. Cambridge: The M.I.T. Press, 1966.

Mitzel, H.F. Teacher Effectiveness. Encyclopedia of Educational Research. New York: The Macmillan Co., 1960, p 198.

Nelsen, W.C. "Entrepreneurship and Innovation in Consortia," The Journal of Higher Educrilan, 1972, 43, 544-51.

Peterson, H. Greaı Teachers. New Brunswick, N. J.: Rutgers University Press, 1946.

Phenix, P H Teaching as Celebration, in "Excellence in University Teaching". Columbia, S.C.: University of South Carolina Press, 1975

Polanyi, M. Personal Knowledge. Chicago: University of Chicago Press, 1958.

Pullias, E.V. and Lockhart, A, et al. Taward Excellence in College Teaching. Dubuque, lowa, Wm. C. Brown Co., 1963

Pullias, E.V and Young, J.D A Teacher is Many Things. Bloomington: Indiana University Press, 1969

Rogers, C.R. "The Interpersonal Relationship: The Care of Guidance." Harvard Educaliangl Review, Fall, 1962.

Ryans, D.C. Teacher Rehavinur Can Re Evalualed. The Evaluation of Teaching. Washington, D.C.: Pi Lambda Theta, 1967.

Sa'ace F and I. H. Russell. "Teacher Autonomy and/or Administrative Leadership: Myth or Reality." Conlemporary Education, 1977, Vol. 48, No. 6, pp.225-7.

Schlat feld, R.M. "Recruiting, Appointing and Renewing Faculty: A Shared Responsibility." Nursing Outlonk, 1976, 24, 3, pp.148-154.

Selznick, P. Ieadership in Administration: A Socialnglcal Interpretation. New York: Row, Peterson Co., 1957

Sergiovanni, T. J. Professional Supervision for Professional Teachers. Association for Supervision and Curriculum Developmen1, 1975, pp. 1-7.

Shumsky, A. In Segrch of Teaching Style. New York: Appleton-Century-Crofts, 1968.

Smoch, R.M. "A Taxonomy of College Professors." Improving College and University Teaching. 1969, 17, 226-7.

Van Doren, $M$. The Arrs of Teaching and Reing Taugh1, in Pursuits of Awareness: "The College Student in the Modern World", edited by Ester Kronovet, pp.17-22. New York: Ap pleton Crofts. 